\title{
A Biographical Perspective on Processes of Radicalisation
}

\author{
Jana Meier ${ }^{1}$. Nicole Bögelein ${ }^{2}$ (D) $\cdot$ Frank Neubacher ${ }^{2}$ (D) \\ Accepted: 6 September 2021 / Published online: 12 October 2021 \\ (c) The Author(s) 2021, corrected publication 2022
}

\begin{abstract}
This article reconstructs four ideal types of biographical self-descriptions outlining radicalisation processes that are based on longitudinal biographical interviews conducted with male (former) right-wing extremists. In the first self-description, the biographers explain how they were born into radicalised families whose ideological norms and values they adopted without question. The second self-description outlines how the biographers' actions were guided by a longing for stability and community. Initially, ideology plays a tangential role, with involvement in Kameradschaften and violence providing key momentum. In the third self-description, biographers refer to their German heritage and glorify National Socialism. They see themselves as guardians of the German Volk, and partly resort to violence to defend this idea. The fourth self-description outlines engagement with right-wing extremism as an outlet for frustrations with social discrimination. During our analysis, we examine whether any of these ideal types also correspond to self-descriptions given by Islamists, concluding that the latter do indeed describe their pathways into radicalisation in a similar manner.
\end{abstract}

Keywords Right-wing extremism · Narrative criminology $\cdot$ Biography $\cdot$ Qualitative research · Empirical study

\section{Introduction}

Right-wing extremism poses an obvious risk to individuals, society and the democratic order both in Germany and throughout Europe. Research that provides insights into processes of radicalisation - that is, an engagement with right-wing extremist views and violent acts-is thus necessary. The many violent crimes that have been committed by right-wing extremists in Germany in recent years attest to the growing relevance of the

Kameradschaft translates as "comradeship" or "fellowship" and is a title often adopted by far-right militant groups.

Nicole Bögelein

nicole.boegelein@uni-koeln.de

1 Zentrum Technik und Gesellschaft (Center for Technology and Society), Technische Universität Berlin, Kaiserin-Augusta-Allee 104, 10553 Berlin, Germany

2 Institute of Criminology, University of Cologne, Albertus-Magnus-Platz, 50923 Cologne, Germany 
phenomenon $^{1}$ and indicate rising social tensions and polarisation (Zick, 2017, p. 16). ${ }^{2}$ Right-wing extremism goes beyond right-wing populism, the latter of which is based on a distinction between "the people" and "the elite", nativism and populism (Boehnke $\&$ Thran, 2019). Although, as a phenomenon, right-wing extremism cannot be subject to a single definition (much like Islamism; see Snow \& Byrd, 2007), at its core lie central components of extreme right-wing ideologies ${ }^{3}$ : assumptions of inequality based on innate characteristics or cultural features that overemphasise one's belonging to a specific ethnic group, xenophobic or racist attitudes and group-focused enmity whereby individuals "are judged to be unequal and subjected to the hostile mindsets of denigration and exclusion based on their chosen or assumed membership of a group" (Heitmeyer, 2005, p. $6^{4}$ ). In general, a key feature of extremism is the construction of a singular self-identity that is outwardly defended (Berger, 2018, p. 579). Furthermore, right-wing extremism is characterised by visions of an authoritarian and anti-democratic order and the promotion of violence as a means to achieve this goal. Manifest right-wing extremism is expressed in politically motivated criminal acts and in membership of far-right political parties, Kameradschaften and subcultural groups (see Frank \& Glaser, 2018; Pfahl-Traughber, 2006).

In this paper, we reconstruct ideal-typical biographical self-descriptions based on respondents' chosen self-portrayal. This enables us to understand latent elements and motives behind certain actions. We take a narrative criminology approach, whereby analysis is based on the stories told by offenders (see Presser, 2009). We investigate how the radicalisation process unfolds from a biographical perspective. Narrative analysis looks at the narrator's life to see how extreme orientations create a sense of identity and guide actions, thus allowing relevant patterns of orientation to be identified for the radicalisation phase (see Frank \& Glaser, 2018, p. 358). The fundamental assumption of biographical analysis is that far-right behavioural and patterns of orientation develop throughout a lifelong process during which family histories as well as extra-familial and life experiences interact (see Köttig, 2008). In line with a genuinely qualitative research logic, the reconstructed self-descriptions emphasise those elements stated as relevant by the interviewees; no external concepts are imposed. They lead to an empirically founded classification of biographical self-descriptions of far-right radicalisation. During our analysis, we examine whether applying these self-descriptions to research into Islamist radicalisation would be constructive.

In the opening section of this paper, we define the term that underlies our analysis—radicalisation-and provide an overview of existing research. We then go on to describe our methodology and sample. As we present our findings, we discuss each of the four reconstructed typical biographical self-descriptions in turn while simultaneously looking at their

\footnotetext{
1 Between 2000 and 2007, a group calling themselves Nationalsozialistischer Untergrund (National Socialist Underground) committed numerous murders and bomb attacks. 2015/16 saw a peak in politically motivated violent offences targeted at refugee accommodation centres. In October 2015, a right-wing extremist stabbed a candidate running in the Cologne mayoral elections. In July 2016, a young right-wing extremist killed eight in a politically motivated attack in Munich. In June 2019, a politician was shot dead by a rightwing extremist in Kassel. In October of the same year, two were killed during an anti-Semitic attack in Halle. And in February 2020, nine people were murdered during a racially motivated attack in Hanau.

${ }^{2}$ See Kruglanski, Webber and Köhler (2019, pp. 8 et seq.) for an overview of the history of right-wing extremism in post-war Germany and a description of currently active parties.

3 Elshimi (2015) demonstrates that there is generally a plurality of perspectives with regard to Islamism, and this also applies to right-wing extremism.

4 All citations have been translated by Nivene Raafat and Lyam Bittar unless otherwise stated.
} 
relevance for Islamism. Finally, we draw conclusions and set out the limitations of this study as well as possible areas for further research.

\section{The Term “Radicalisation” and Selected Current Research}

We understand radicalisation processes as the process of turning to extremist attitudes. Building on Kemmesies (2006), we pragmatically consider extremism to be the attempt to change the social status quo, i.e. the free democratic order, using non-democratic, illegitimate means, including violence (p. 11). In line with the general discourse (see McCauley \& Moskalenko, 2008), in this article we focus on the radicalisation of non-state individuals and groups. Like McCauley and Moskalenko (2008, p. 416), we understand the process of radicalisation as follows: "radicalization means change in belief, feelings, and behaviors in directions that increasingly justify intergroup violence and demand sacrifice in defense of the ingroup."

Definitions of "radicalism" or "danger" are invariably political and linked to the interests of national security agencies. Jukschat and Leimbach (2019, p. 11) call the term "radicalisation" a "hegemonial paradigm" due to its normativity. Those who are "radicalised" are drastically constructed as a socially problematic group (see Coppock \& McGovern, 2014; Leimbach, 2019). Deradicalisation and exit programmes have their roots in neoliberal governmentality (see Elshimi, 2015; an overview of counterterrorism strategies is offered by Hellmuth, 2015, pp. 86 et seq.). We are aware of these issues and so in this study, we examine individuals who have been convicted of relevant criminal offences and who have either thus been labelled "radical" or who self-identify as such; in any case, they have already had to grapple with this label.

During the process of radicalisation, a range of factors take effect at multiple levels (Bögelein et al., 2017; Borum, 2011a, b; Frindte et al., 2016; Kruglanski et al., 2019; Zick, 2017). These operate not just on the individual, i.e. micro level, but also on the societal macro level (e.g. discrimination, injustice, conflict) as well as on the meso level, i.e. within groups (sense of community, friend-enemy distinction, group processes) (Meier et al., 2020; Frindte et al., 2016, p. 11).

What specific factors influence a person's political radicalisation? Key influencing factors are perceived negative treatment by the police, a belief in law-abiding behaviour and risk seeking (Baier et al., 2016). Frindte et al. (2016) suggest radicalisation is the result of an inability to satisfactorily perform age-specific developmental tasks, such as belonging, acceptance and emotional support. Radicalised scenes offer solutions as well as tangible support to help deal with these developmental tasks. Social contacts, in particular, appear relevant (see Möller \& Schumacher, n.d.). Those who turn to radical scenes display a lack of system integration (e.g. in terms of school) and consider themselves to be permanently and systematically disadvantaged, although this may not objectively be the case. They often lack communication skills, self-esteem and a capacity for empathy, and endorse masculinist ideals. Right-wing extremists often foster certain traits of "hegemonic masculinity" (Connell, 1995) shown through openly expressed attitudes and beliefs, e.g. heterosexuality, starting a family, serving one's people and nation, a military mindset, unwillingness to compromise and toughness as well as acting as a leader and key decision-maker (Virchow, 2011, p. 42). Pfeiffer (2016) observes that individuals are especially likely to come into contact with the far-right scene through family-with grandfathers, in particular, acting as a "catalyst" (p. 458)—school or within music and sports communities, a context for which 
he coins the term "right-wing extremist experience" (Glaser \& Pfeiffer, 2013). Music plays a significant role in the dissemination and development of far-right culture (Shaffer, 2017). An increased sense of patriotism is a risk factor for the restriction of certain groups' religious rights (e.g. with regard to the construction of mosques) even among those who hold democratic beliefs (Canan, 2017).

Kraus and Mathes (2010) examined similarities between offenders classified by the police as right-wing extremist and other types of offenders. Offenders motivated by farright ideology more frequently committed violent crimes and there were considerable similarities between this group and non-political violent offenders. At present, those suspected of far-right violence are no longer typical young delinquents; a shift is taking place in the age structure of suspected perpetrators of far-right violence. While in $2007,51 \%$ of suspects were juveniles and young adults, by 2017 , this figure had sunk to just $7 \%$, i.e. offenders are getting older (Laube et al., 2019). Willems and Steigleder (2003) also refute the theory that violent far-right offences can be considered typical adolescent acts, and instead, based on the based on the combination of offender and victim and the motive, consider them to be hate crimes.

Lützinger (2010) analysed the biographies of far-right extremists and identifies influences from explicitly ideological groups. Individuals interested in the ideology sometimes actively contact such groups, seeking their protection. Existing groups can also become radicalised. Furthermore, shared political interests can bring like-minded individuals together, and, finally, individuals are targeted for recruitment by radicalised groups. Adolescents who do not identify with far-right ideology tend to join more traditional groups, such as sports clubs, compared to adolescents with far-right views (Möller \& Schumacher, n.d.; Becker, 2010). Carlsson et al. (2020) also emphasise the importance of groups. In interviews with former extremists, they identified three basic conditions for radicalisation: poor social controls, interaction with individuals close to ideological groups as well as a stage of "meaning-making" and finding a sense of purpose within the group. Aligning one's identity with one's relationship to the group increases the individual's willingness to engage in violence on its behalf. In their empirical study based on interviews with former right-wing extremists, Kruglanski et al. (2019) found evidence to support their $3 \mathrm{~N}$ model of radicalisation, which is based on three essential elements: "needs" (of those becoming radicalised), "narratives" (cultural narratives that set out how commitment to the movement satisfies the aforementioned needs) and "networks" (that exert both an informative as well as a normative influence). Snow and Byrd (2007) also explain, taking Islamism as an example, how important the framing of a radicalised social movement is for mobilisation; this must be diagnostic (what is going wrong?), prognostic (what needs to be done?) and motivational (why am I doing it?).

In terms of the radicalisation process itself, studies demonstrate a range of processes at work. Eckert (2013) identifies stages in which hostility towards those seen as foreign leads to xenophobia and, ultimately, to far-right ideology. Feeling unsettled by the unfamiliar leads to group consciousness and the exclusion of others who are considered to be "worth less". This then increases the perceived threat and, ultimately, innate characteristics are accorded higher value while those without such features are seen as inferior. These moral values finally become absolute, superseding all other loyalties. In a study of the far-right skinhead scene, Möller and Schumacher (n.d.) were able to identify four patterns of radicalisation (see Möller \& Schumacher, n.d.): "Witnessing interethnic competition", "Belief in the cultural hegemony of interpretations based on racial hierarchies", "[Political] supplementation of the partial integration of youth culture" and "Community rebellion". Bögelein and Meier (2020) identified four typical paths into radicalisation. "Path dependency" 
sees individuals led into radicalisation by their immediate social environment; there is no political motivation. Then, there is a stage in which self-evident truths amalgamate into convictions ("self-evident-turns-into-conviction"). While extremist ideology might be present in their social environment, ego specifically seeks out contact to external radical groups. In "allegiance", the individual encounters the ideology through a group, with ego initially looking for belonging rather than political affiliation. In "ideology", no right-wing extremist ideology is present in ego's immediate social environment, which is why ego actively seeks out far-right groups that share its convictions. Lastly, a study by Colvin and Pisoiu (2018) demonstrated that far-right violent offenders invoke the values of their subcultural scene and the fundamental values of the wider culture to justify their offences. In contrast to non-political offenders, they make no secret of their objective to establish their ideology as the wider societal norm, e.g. by using certain tropes-allusions to their underlying ideological beliefs-as a matter of course (e.g. disparaging terms for certain groups).

\section{Data and Methodology}

\section{Biographical Research}

In line with sociological biographical research, we understand "biographies" to be a social construct that is neither inherently individual nor subjective, but refers to collective rules, discourses and social frameworks. In its lived course and retrospective examination, biography is always both an individual and a collective product (Rosenthal, 2014). Biographical research analyses biographical constructions that individuals develop to interpret their own life and to build on a blueprint that can guide their actions and life course. This research also contributes to the process of gaining an understanding of the other, i.e. an understanding of the lived process of becoming who we are now (Rosenthal, 2014). Our aim is to seek out process structures within individual biographies as, like Schütze (1983, p. 284), we proceed on the assumption

that there are elementary forms of these process structures which, in principle, are present in all life courses - even if only marginally in some cases [...] and that there are systematic combinations of such elementary process structures that are socially relevant as they offer certain predestined life trajectories.

Our understanding of biographies differs from prevention projects that work with former extremists (for an overview, see Gansewig \& Walsh, 2020) where biographers are attributed a natural, individual authenticity and the story itself is used to serve a certain purpose. Our approach involves reconstructing how the narrator perceived an experience as it took place and thus aims to reveal the structures that shaped the narrator's course of action. Our aim is not to ascertain the truthfulness of the account. Empirical social research, which is always based on retrospection and thus subject to rationalisation, can never fulfil this aim. The following analysis makes a valuable contribution to existing research by pinpointing ideal-typical biographical self-descriptions established, in the tradition of reconstructive research, via an analysis of individual narratives.

The biographies were collected during narrative interviews with individuals who are or have engaged in right-wing extremism or Islamism. These interviews were analysed based on Rosenthal's (1995) interview analysis method: first, we analysed the biographical data/ 
sequence of events. By putting forth initial and subsequent hypotheses, the experience at the time of an event (experienced life history) is reconstructed and a hypothetical structure is developed that reveals the mechanisms governing the action taken by the biographer in their narrative. In a subsequent step, text and thematic field analysis, the main interview narrative is sequenced according to the speaker, the text type and the theme. The purpose is to reconstruct the biographer's self-interpretation (narrated life story) and to ascertain the interest guiding their framing of the past. The reconstruction of the life history enriches biographical data with extracts from the interview to support, expand or dismiss hypotheses. These steps were enhanced with detailed analyses of incomprehensible, ambiguous or particularly interesting sections of the interview. Moreover, we analysed the initial stages of the conversation for each interview as the biographer's selective responses during this phase provide key information about their motives for a certain self-portrayal. The final stage, in which we contrast the narrated against the experienced life history for each case study, highlights differences between the two levels, i.e. between the biographer's past and present perspective. Subsequent to an analysis of each individual case, a "comparative contrast" (Bohnsack, 2014, p. 26) was conducted, which allowed ideal-typical self-descriptions to be established based on constituent features (see Kelle \& Kluge, 2010), which form the results of our analysis. In the "Ideal Types of Biographical Self-descriptions of Radicalisation" section, we outline the four resulting biographical self-descriptions of radicalisation.

\section{Description of the Sample}

This was a longitudinal research project. Between April 2018 and July 2020, we conducted biographical narrative interviews in two waves. Of the 21 males $^{5}$ surveyed in wave 1 , nine respondents can be categorised as far-right extremists and three considered Islamists. One person was an (apolitical) violent hooligan and another was formerly active with Antifa. Although we focused on individuals who are or were either right-wing extremists or Islamists, there were seven additional interviewees who-in addition to the apolitical hooligan and the former Antifa activist-were not suitable for our sample and thus not included in our analysis. ${ }^{6}$ After 12 months, we were able to conduct a second wave of interviews with eight individuals (seven from the farright scene, one Islamist). The following analysis thus draws upon a total of 20 interviews with twelve individuals. The interviews lasted between 34 and 172 min and the majority were conducted in prisons. The respondents were aged between 23 and 43 at the time of interview. Eight individuals have experienced (sometimes severe) violence within the family setting; seven respondents grew up in single-parent households, with grandparents or in care, and one sought refuge in Germany as an unaccompanied minor and lived in the country without any parental supervision.

\footnotetext{
${ }^{5}$ It was not our intention to only speak with males, but we were unable to find a female willing to be interviewed. However, the world of organised, violent far-right extremism is generally male dominated; over $90 \%$ of such offences are carried out by men (Bitzan, 2017).

6 They contacted the team for interview because their prison and other institutions were convinced their religious beliefs also implied that they must hold radical views (see also the remarks made by Coppock \& McGovern, 2014, on how young British Muslims are constructed as a "suspect community" and thus subjected to state surveillance). However, they presented neither radical views nor evidenced any form of close contact to right-wing extremist or Islamist scenes when interviewed and so could provide no relevant material regarding radicalisation.
} 
The point at which interviewees became involved in right-wing extremism differs considerably. Two respondents were born into a right-wing extremist family, i.e. they have been exposed to far-right ideology since birth. Five of the respondents encountered the far-right scene in their (early) youth, between the ages of ten and 16. Two individuals became involved in the scene relatively late: despite showing xenophobic views early on, one interviewee only became actively involved in organised farright groups at 28 . The other respondent only encountered right-wing extremism in their late 30 s, going on to commit serious, politically motivated offences. At least six respondents are or have been involved in Kameradschaften and/or political parties and have committed politically motivated violent crimes. Two respondents were participating in deradicalisation programmes at the time of interview, two others have independently distanced themselves from far-right ideology, and the remaining five (partly due to their incarceration) have cut ties with right-wing extremist organisations but have largely retained right-wing views, with their ideology sometimes becoming more extreme in the prison setting.

Among Islamists, motives and pathways into radicalisation also differ. One respondent grew up in a strictly religious environment with a family that became radicalised during his youth and migrated to their country of origin (from which they had fled to Germany) to join an Islamist movement. An-initially non-practising-Muslim turned to Islamism at barely 20 years of age, and the third respondent-also just before turning 20-developed a close bond to a devout Muslim male and became radicalised. Two of these men gave up heavy alcohol and drug use after engaging in Islamism, and all three were active in Islamist group structures throughout their radicalisation. However, none committed an act of ideologically motivated violence. Two respondents have distanced themselves from radical ideology during their prison sentence; it remained unclear whether this is also true for the third.

\section{Ideal Types of Biographical Self-descriptions of Radicalisation}

The following section presents four types of biographical self-descriptions of radicalisation that we have reconstructed based on the self-presentations given by the interviewees (hereafter referred to as "biographers"). The various ideal types were reconstructed based on the 16 interviews (from waves 1 and 2) conducted with nine right-wing extremist biographers. In a subsequent step, we examine each ideal type in turn to assess its relevance for the four interviews (taken from both waves) conducted with three Islamist biographers.

The first names stated in the following sections are all randomly chosen pseudonyms. This is partly to improve the readability of the article (compared to using, e.g. code names) but also to ensure the biographers' anonymity. To illustrate how we identified the four ideal-typical self-descriptions, we offer specific examples and particularly relevant, extensive extracts from the interviews, which also provide an authentic view of the lifeworlds of the biographers and their justifications for their actions. These extracts have been edited slightly to improve readability. The identified types are initially described in abstract form and then illustrated more specifically using examples from the biographies. 


\section{Born into the Profession}

In this ideal type (taken from an interview with Marc), the narrator is born into a farright ideology that is presented as perfectly normal and defended through the use of violence and criminal offences. Within the family context, the biographers are subjected to an extreme worldview and its associated values without being able to consider whether they share these ideas. The narrator is made-under the use of, sometimes violent, authoritarian force-to adopt the family way of life by the parental generation, usually a dominant father. Over time, however, the ideology becomes an active and violent part of life. The biographers initially offer a detailed description of their radicalism and their substantial involvement in the scene, before outlining their deradicalisation; this biographical self-description is only given by former extremists. The process of becoming deradicalised begins during adolescence when young adults start to critically question their role within the family and their ideology. This distancing is triggered by a relationship that is strictly prohibited by the family's ideology. As the family has such close ties to the far-right scene, distancing oneself from the ideology invariably means distancing oneself from one's family. Here we can draw parallels to Sigl's (2018) "Disengagement as emancipation from the family and social consolidation" pattern, which also refers to involvement with an ideology through one's family that begins in childhood. In her model, too, deradicalisation is only possible if the subject steps away from their family.

Biographer Marc highlights the unique nature of his radicalisation when he says: "I was pushed into the profession, grew up in it and RAISED that way, too." His choice of words emphasises the passiveness and the need to adopt his family's traditions. During his upbringing, he was subjected to far-right ideology and grew up in a "profession" that was strictly isolated from mainstream society, as the following extract illustrates:

"That was always strictly off limits. They always said, ONLY us, only our views, only our club, only our ... Yes. So, only what was in that circle. Anything beyond wasn't part of US. Was nothing to do with us. Was nothing we had contact with." (Marc)

Being cut off from the outside world makes it difficult to challenge the far-right ideology. The biographer's emphasis on "ONLY", "we" and " $u$ " also makes clear a feeling of elitism: he is a member of a group that defines itself as superior (see Berger, 2018, pp. 54 et seq.).

Franz is also born into a far-right family. During his youth, he is exposed not only to ideological meetings between adults but to alcohol, drugs and crime, and his upbringing is shaped by violence. He forms close attachments solely to family members and his parents' far-right friends as well as their children. There is no contact with children outside of this ideological context. This is partly because Franz is taught in constantly changing schools, making it difficult for him to establish relationships with peers, which is something his parents wish to avoid. He feels he belongs in the far-right scene:

"So with skinheads. With lots of skinheads. That was like, you know, my place, where

I felt I belonged. Where I, like, felt this strong sense of community. People always happy to see you there. And, of course, to force their crap down your throat, to put it bluntly. But at that time, they were just like my family, they were friends. And what they did was normal for me. I mean, I didn't know anything else." (Franz)

Isolation from mainstream society as dictated by their ideology is, as shown in this biographical self-description, actively pushed by the parental generation as outlined 
above and is a key aspect in the biographer's life. Far-right ideology forms a constant during a childhood and adolescence marked by a lack of emotional security and protection within the family. Marc's relationship to his mother is strained; his far-right father's parenting style is authoritarian and violent. Nonetheless, the latter serves as a role model for Marc, who not only accepts but actively supports this worldview, not least to please his father. His father's reaction to Marc getting a swastika tattoo at the age of 13 illustrates this convincingly:

"Took off my T-shirt and then he saw the tattoo, his eyes just LIT UP, so much JOY! He grinned, said, 'Oh, that's fantastic!' I thought to myself, like, er, sweet, okay, of course, cool, great, I was like, 'Yeah, sweet!' I mean, come one, who tattoos a swastika on the chest of a 13-year-old?" (Marc)

In Franz's life, too, an emotional insecurity takes hold, exacerbated by constantly changing living arrangements, and right-wing extremism begins to take on an important role. Franz becomes involved in the far-right scene, even away from his family, and engages in political violence. In his life story, however, deviant behaviour also takes place beyond the far-right scene, an example of concurrent non-political offences (see Kraus \& Mathes, 2010). Yet, the intensity and frequency of offences exceed normal, ubiquitous and episodic juvenile delinquency (see also Willems \& Steigleder, 2003) and the offences are often racially motivated:

"And if some foreigner comes along and, just, you know, gives you a dirty look and you're already geared up for the whole 'Hey, what does he want?' And then it just blows up in an instant. And you don't hold back at all, you just swing away. And that's what I did." (Franz)

Marc, too, encounters violence, not only at the hands of his father but also as a perpetrator. He emphasises that although he was born into the far-right scene, he did not remain passive. It is important for him to have agency, which he acquires by exerting power over others. Here a feeling of elitism drives his actions. He employs physical strength and stresses that he can hold his own. In addition to offences that are not linked to the far-right scene, such as drug trafficking and tax fraud, he also commits far-right offences, such as violent participation in political demonstrations and blackmailing, abuse and attacks targeted at individuals perceived as foreign:

"If there were, like, some Arabs or African people that I encountered on the way to school, I'd pull off their school bag, give them a wallop, batter them, to let them know: 'You don't belong here, piss off!'” (Marc)

Throughout the interviews, Marc and Franz present themselves as former members of the far right and deride the ideology both linguistically and in terms of its values. Both are able to free themselves from the ideology and their respective families through relationships with women who belong to groups that they once looked down upon, and they begin to question the far-right ideas that had previously shaped their lives and their thinking. Franz summarises this transformation in the following:

"I was, well, like I said, geared up for it. Like: 'If it's not German, it has no place here,' to put it plainly, you know. That's how it was. Otherwise none of it would have happened. But that's all gone. Now I despise it. Because everyone has the right, irrespective of where they come from, their ethnicity, what dialect they 
speak, whatever. We're all human beings. And I think being together is better than

being against one another." (Franz)

Can the "Born into the profession" ideal type be applied to Islamism? One of the Islamist biographers, Jamal, describes how he is born within a devout community into a family that is becoming radicalised and lacks external influences. His childhood is marked by uncertainty surrounding his residential status as a refugee in Germany, reliance on state benefits and structural discrimination. Furthermore, there were challenges within the family, such as his parents' separation and separation from his stepfather, as well as an authoritarian upbringing occasionally punctuated by violence. A mosque, which also provides a forum for radical imams, is a key setting for his family. Jamal appears to show little interest in the quasi-religious ideology and instead devotes his time to activities usually enjoyed by teenagers: "[A]t that time, I played this game, Warcraft, and I [...] sort of wanted to go to the sermon [in the mosque], but I also wanted to play". But he becomes radicalised along with his family, adopts the ideology without question and emigrates to join a militant Islamist movement. Jamal portrays himself as a passive follower, echoing the right-wing extremists on which this ideal type is based. However, Jamal does not attribute the same level of importance to his disengagement from the ideology as those (former) far-right biographers as it is not addressed in his interview.

\section{Kind of Looking for a Family}

A longing for support and a sense of community that are lacking in the family of origin or in foster or children's homes underlies this ideal type, the title of which is taken from an interview with Damian. Biographical disruptions and difficult stages of life are interpreted as triggers for a shift towards right-wing extremist structures. In this ideal-typical biographical self-description, too, the biographers are initially victims within the family before becoming perpetrators of violence. Early contact to Kameradschaft members is also characteristic; given the lack of social ties, members seem to be targeted for recruitment into the scene. Kameradschaften know how to offer potential members just what they are looking for. The right-wing extremist experience (Glaser \& Pfeiffer, 2013), which is shaped by solidarity, shared activities and collective acts of violence, is (initially) more important than ideology. The determinant factors of this type of biographical self-description are a childhood spent in a family where conflict is commonplace, experience of disintegration in one's school and professional career, deviant behaviour and an attraction to right-wing extremist groups that is driven more by personal rather than ideological motives, as the examples demonstrate (see also Gansewig \& Walsh, 2020).

Disruptions and discontinuities in both private and institutional settings have an impact on biographer Damian's life. As a child, he experiences violence and abuse within his family and grows up in foster/children's homes. His educational and professional life is also marked by instability. Despite positive experiences with some parental figures, he does not feel he belongs to the world that exists beyond the far-right scene. This ideal-typical selfdescription is characterised by longing: "Well, I'd say I was kind of looking for a family, and in the far-right scene, that's where I found my place" (Damian). The far-right scene offers a sense of belonging, solidarity and community and is one constant in an otherwise chaotic life. Damian uses his early experiences of violence to justify his high propensity for violent behaviour: 
"Violence has actually shaped my entire life so far. Whether the fact that back then, in/ when I was around four, I witnessed my stepfathers, you know, battering my mum (.) or sexually abusing my siblings/ sisters. So violence was always a big part of my life." (Damian)

Violence and crime play a key role in this type of biographical self-description. For Damian, too, violence is a hobby, with opponents and occasions for such behaviour being of minor importance. Football matches and far-right demonstrations are opportunities for confrontation with political opponents (i.e. Antifa):

"I actually only found the protests interesting because of the violence. Yeah, it was like my second hobby after football. Like all the fights with Antifa. So that was actually the main reason why I actually showed up at all the protests." (Damian)

Damian also gradually becomes susceptible to the ideology. He joins a Kameradschaft and supports the election campaign of a right-wing party under surveillance by Germany's domestic intelligence agency, also gaining a sense of solidarity from political discussions. He continues to perpetrate violence away from the scene as well, and his acts soon far exceed the typical level of teenage delinquency:

"What have I done? Theft, embezzlement, dealing in stolen goods, blackmail, vandalism, assault, assault, assault, grievous bodily harm. Mental CRUELTY, assault, grievous bodily harm, theft, assault as part of a group, breach of the peace on several counts. Grievous bodily harm with an object. Is that what it's called? With a weapon, I think." (Damian)

A characteristic feature of this type of self-description is an engagement in and disengagement from the scene that take place at a very young age (no later than early adulthood). Disengagement - for Damian, this was initiated by the sight of his younger brother scribbling swastikas and Damian's desire to be a better role model to him-means the cutting of all ties with the previous milieu, which consists exclusively of scene members, as well as an end to delinquent behaviour. The most important issue for Damian thus remains a search for belonging. Damian is able to undergo this significant change thanks to the support of a deradicalisation project, with support workers taking on a key role. Making a fresh start ideologically is also important in this ideal type as the old ideology is unlearned and reconsidered from a critical standpoint. Damian had already independently chosen to reject the ideology.

Can this typical self-description, "Kind of looking for a family", which describes radicalisation as the result of a longing for support and community, also be found in Islamism? Murat and Valentin argue that their radicalisation was driven by such motivations. Both turn to Islamism during difficult periods in their lives, become significantly radicalised and find structure, reliable friendships, food and shelter, as well as meaningful norms and values, within the community structure. Both turn away from their families, as well as nonreligious friends, and live solely in this radical group.

Murat's non-religious parents immigrated to Germany. He encounters violence in his family, has issues at school, is violent himself and commits criminal offences. After receiving support from youth services and a relationship breakdown, he falls into a depression, starts drinking and begins researching Islam online:

“Because I just didn't get on with my parents and was just drinking and hanging around at home and watching these IS videos. Then you just eventually lose all sense of reality, like. Then eventually you just want to get out there, simple as. And it's 
about escape but you're also a bit fed up with everything. So you just don't want, I just lost the will to live, that was it. But I didn't have a life. Just alcohol, drugs and then a bit of Islam. I just couldn't bear myself." (Murat)

In his search for purpose, he finds what he is looking for at a radical mosque, where he joins the worshippers, stops consuming alcohol and becomes radicalised within a short space of time:

"There was a man, he told us he was in Syria and fought and lost his leg and everyone was so in awe of him, yeah, look at him, he's been there and stuff. I admired him too, because everyone gave them so much respect, they are basically kings. Yeah, he said that he went and how great it is and stuff and to fight for God, that we shouldn't listen to the news and that we should just focus on Islam. That it's the right path." (Murat)

Murat dresses and lives according to strict Islamic code, takes part in missionary work and decides to travel to Syria to carry out a suicide bomb attack, but he is arrested.

Religion also plays no role in Valentin's household in a Muslim-majority country. After his father is murdered in a politically motivated attack, his mother sends him to Germany at the age of 17 out of fear that he might be recruited by Islamist groups. Upon arrival, he befriends a group of "compatriots" (Valentin) and engages in an intensive period of deviance and drug use. When he meets a devout Muslim, who becomes his "spiritual teacher" (Valentin), he stops taking drugs and offending. He later establishes his own strictly religious group and actively spreads IS propaganda. He is sentenced to several years in prison for his role as an "information activist" (Valentin) online. Both biographers justify their radicalisation as a longing for support and community, exactly like the right-wing extremists on whose accounts this ideal type is based.

\section{A Decent, Staunch, Upright German Family}

In the "A decent, staunch, upright German family" (Rico) self-description, the process of far-right radicalisation can be traced back to traditions within the family, whereby emphasis is placed on perceived German values, such as strength, respect and order. The (great-) grandparents' generation openly glorify National Socialism (on the importance of family, see Pfeiffer, 2016) and pass on these attitudes to subsequent generations. One feels as though one has been born into an elite group and looks down on those who look or seem different. (Violent) offences are thus justified as having origins that are perceived to be superior includes the right to pursue one's own interests using violence (see Colvin \& Pisoiu, 2018). The literature also makes reference to a "fascination with historical National Socialism" as well as "its relevant values or worldview promoted within the family of origin" as a cause variable for far-right radicalisation (for an overview, see Gansewig \& Walsh, 2020). Even if those who would use this self-description decide to disengage from right-wing structures over the course of adulthood to go on to lead a crime-free life, they do not distance themselves from the ideology as the values of National Socialism and their assumed superiority are deeply connected to the way they view the world and themselves.

Biographers Rico and Christoph offer prime examples of this ideal type. Rico summarises the values guiding his actions as "unity, strength, resolve. Having RESPECT for each other, the country, your mother, your grandmother, your grandfather". In contrast to "Born into the profession", the focus here is not on having been arbitrarily born into a certain 
family but pride in the family tradition, which is predicated on National Socialism (in line with the findings put forth by Möller \& Schumacher, n.d.):

"I visited my great-grandpa every day. He always gave me a banana and a piece of chocolate. And then he told stories and talked about the war. I listened to all the stories, like the heroic tales and so on. He never saw the war as a bad thing. He had been on the front lines, he served under Rommel. He was the proudest man in the world. And then they put him in his SS uniform, his magnificent black uniform. For me, that's just something, when you see the pictures. Just amazing that he still had his uniform. It's mine now. Let me tell you, it's an incredible HEIRLOOM. And when he put his SS uniform on at the age of 90, when you saw how this stooped man suddenly stood straight as a rod again. Well, you can't say a word against it. It CAN'T be wrong. Even when he was in a care home, he still had Adolf hanging above his bed. No one was allowed to touch it, not even to clean it. That was just his life, it was his world. And that's what I saw from a young age, I never learned otherwise." (Rico)

This inspires Rico's own far-right ideology; he idolises the generation of his (great-) grandparents, who are role models to him, and places more faith in his great-grandfather's tales than in other sources. His great-grandfather's pride rubs off on him; his own family's history romanticises the crimes committed by Germany during the Second World War. His conclusion that National Socialism could not have been wrong if his great-grandfather was an enthusiastic follower is a characteristic feature of this self-description. This pronounced idea of elitism is applied to the modern day:

"And there [in initial accommodation provided to refugees] I learned to tell the difference between those that really NEED help and those swine that don't belong here. I also think there are lots of Germans who don't belong here. This is the land of poets and thinkers. We're doing something for our country. We're fighting for ourselves, and not people on benefits and I'm happy with that. We don't need that." (Rico)

Rico expresses group-focused enmity (see Heitmeyer, 2005) and legitimises violence against groups that do not conform to the "German values" (Rico) that he considers important. This can apply to anyone, regardless of their nationality or background. This selfpresentation does not address the discrepancy between the narrator's own actions, which are characterised by delinquent behaviour and result in a (significant) prison term, and the German values held in such high esteem.

Traditional gender roles - with masculinity associated with strength and determination (for more on hegemonic masculinity in right-wing extremism, see Virchow, 2011) — and a marked interest in militaria and weaponry also form part of this self-presentation. Christoph practises martial arts and collects traditional firearms and other weapons: "My father, too, always had quite a lot of weapons and stuff like that hanging on the wall. Ammunition belts for machine guns and stuff." He enlists with the German Army where, he states, he is likely to come into contact with right-wing extremists.

Rico is able to live out his racist and discriminatory worldview in Kameradschaften. His membership gives him a sense of identity and affirmation:

\footnotetext{
7 The authors strongly oppose any expressions used to disparage individuals or groups of people. However, we feel it is important to document these words in the context of our scientific analysis. Such dehumanising terms, which appear in many of the interviews we conducted, will be only reproduced minimally here so as not to encourage their use or proliferation.
} 
"And then I got roped into the first Kameradschaft. Where we lived, it was the Hammerskins back then. At 16, I first had contact with Blood and Honour, then [Kameradschaft] that I cofounded. And then I gradually climbed up the ranks." (Rico)

He commits several politically motivated offences, during which he describes himself as a custodian of German values, and employs violence, for example against people who use or sell drugs. The following extract shows just how deeply group-focused enmity (see Heitmeyer, 2005) is also rooted in Rico's worldview. He refers to this ideology to justify the use of violence and also the offences he commits in order to enrich himself:

“'Druggies, people with some kind of addiction, junkies, people who don't deserve to live' is what they used to say. 'People who poison themselves don't deserve to live.' We just took the junk off those people, chucked it down the drain. Took cash, phones. Got rid of all that poison so it wouldn't carry on infecting the town, stuff like that." (Rico)

The discrepancy between his own criminal behaviour and the condemnation and denigration of those considered to be inferior is a characteristic feature of this ideal-typical biographical self-description and illustrates a pronounced sense of elitism.

Identification with a football club also plays a role in this self-description. The game itself is a way to bring members of the group together: "[S]itting around with comrades, football and raising our right arms and playing the national anthem and watching football' (Christoph). But Christoph also sees his team's games as an opportunity to engage in violence:

"Always went to the stadium at the weekend, always went to the football, you know. And I got involved in a scuffle every now and then. Fell in with the hooligan crowd a bit. Whatever that means. Never was actively involved in the hooligan scene, but I was in with those people. We would meet up, you know, at the ground or after the game and we'd just, you know, fight a bit and stuff, you know. Just to see who was strongest." (Christoph)

Elsewhere, too, this self-description paints a picture of a biographer who, armed, dominant and menacing, endorses violent behaviour and places importance on masculinity: "Robbery, blackmail, collecting payments. That's how you make money. And doing it on request. You just go with the one who pays best" (Rico). The focus of the self-presentation shifts over the course of the narrative. He distances himself from his deviancy and goes on to presenting elitist, racist views as part and parcel of German identity. In line with family tradition, this is also passed on to one's children, but the biographer seeks to dissuade them from pursuing a life of crime. This self-presentation sees no reason to distance oneself from far-right ideology: pride in one's own convictions runs deep and is affirmed, even in prison:

"I've got the German Empire flag hanging in my window, IN my cell, I have military stuff in my cell. I've a bedspread in the same colours. I've got an IMPERIAL WAR FLAG as a screen for the toilet, a big, almost two-metre flag hanging in my CELL." (Christoph)

We found no evidence in our interview material to suggest the "A decent, staunch, upright German family" ideal-typical self-description could apply to Islamism. It is, however, possible that it features within Islamism in different ways. A staunchly religious family - much like a staunchly nationalist family — could provide a sense of purpose and 
cultivate an attitude that leads to those with different beliefs being viewed with contempt or even, as radicalisation intensifies, as the enemy.

\section{You Felt Discriminated Against}

This self-description, taken from an interview with Udo, is based partly on a longing for recognition, purpose and solidarity, but it is also characterised by a pronounced desire for power and a focus on authority, which firmly sets it apart from the "Kind of looking for a family" self-description. Despite a few difficulties, the family in this ideal type offers stability and security, and is generally apolitical, or at least not as radical. An individual's family or religious background is thus not the primary driver of radicalisation, which is another factor that sets this self-description apart from the other three. Instead, racist attitudes and a sense of inequality are legitimised by a subjectively perceived feeling of marginalisation. These attitudes are also justified as being the result of social developments and negative experiences with those of non-German origin, not only privately but also in school or at work. This leads to a susceptibility for right-wing populist views (see Boehnke \& Thran, 2019) and a further radicalisation, followed by a period of time in organised right-wing structures involving (violent) crime.

The biographer René portrays himself as someone who is troubled by those that he perceives to be migrants or foreigners, even from an early age, and so when describing his engagement with right-wing extremism, he portrays himself as a victim of social circumstance:

"There were just lots of migrants, lots of foreigners at school, that's just how it is. And I think that's where those thoughts began, when I already started to ostracise people. When I would say: 'I don't want to have anything to do with them. They're speaking some language I don't understand, can't be bothered with that."' (René)

Biographer Udo believes his path into far-right ideology is linked to an event in his private life: his wife leaves him for a man, whom he perceives as non-German:

"And I was, you know, already BOTHERED by FOREIGNERS because of the message I got back then from the wife: 'Left with Mohammed, won't be coming back. Bye." (Udo)

Events such as these are subjective experiences of powerlessness and undermine the image of masculinity seen as desirable in right-wing extremism (see Virchow, 2011). They can turn an existing affinity for right-wing interpretations into a manifest motivation for joining the far-right scene. This ideal-typical biographical self-description is filled with seemingly universal right-wing populist interpretive paradigms: one's own group (ingroup) is seen as being in competition with outsiders (outgroup) (see Berger, 2018 , p. 56). Immigration is considered a security risk and both the labour market and the welfare state appear under threat. Most seemingly under threat, however, is one's own standing. The biographer feels he is socially marginalised and blames those of nonGerman origin for this:

"Yes, and again you felt DISCRIMINATED AGAINST. When you thought, 'I see, the state basically kisses their arse,' and you're the one slaving day after day for your own stuff and have to fork out for everything yourself." (Udo) 
A sharp rise in immigration, mainly driven by those fleeing the civil war in Syria and the German government's decision in September 2015 to take in refugees, reinforced this perception to such an extent that even individuals who follow this ideal type, but had no previous involvement in far-right extremism, feel compelled to seek out such circles:

"That was back in 2015. First, there was this rumour that the hotel would house asylum seekers. So we went there, watched and chatted a bit and had a bit of a gripe and all that. Well, at some point we got talking, and we exchanged numbers, we met up. And, well, had a beer and then the, I'll just say it, the shameful stuff began." (Sandro)

This displeasure is directed specifically at state care provided to refugees and motivates the biographers to actively combat the perceived injustice. This is demonstrated during a situation in which a caretaker shows Udo an apartment that has been set up for refugees. Udo subsequently becomes so furious that he suggests the location as a potential target for an attack on a chat forum with a far-right group:

"[The caretaker] says: 'A Syrian family of five is moving in here. Take a look at everything they've been given.' All brand-new furniture [furniture brand]. The whole place covered in LAMINATE flooring. Huge FLAT SCREEN on the wall. It had all been prepared for them. 'Pff', thought to myself, 'I see. The district office is paying for all of this?' And that made me so AGITATED. I went on the chat: 'The first place on the list should be the asylum centre here in [village X]'." (Udo)

Xenophobic attitudes based on cultural differences and competition over resources considered to be scarce, as outlined in the concept of group-focused enmity (see Heitmeyer, 2005, p. 6), are thus perpetually reinforced, culminating in racially motivated acts of violence. These are then justified by experiences with people perceived as "other", as described by Stefan, who, in his role as a paramedic, assaults people of other ethnic backgrounds:

"And that really shaped the way I saw everything, and I started saying: 'They're all the same!' And, unfortunately, well, not that I want to say they were all the same, but many experiences started to add up and many of them were just demanding things. Mostly coloured people were demanding things." (Stefan)

In this self-description, actions are guided by a focus on authority and power alongside a longing for recognition and solidarity, and this is shown in the following extract from Stefan's interview. He is involved in Kameradschaften and quickly works his way up. Alongside group BBQ parties with alcohol, there is violence and an increasing ideologisation, which leads to active political involvement. Participation in far-right events is retrospectively romanticised and personal responsibility is played down:

"Those kinds of parties were put on, BBQs. We sat around the campfire and there were PARTIES, it was all paid for. Yeah, by those nice folks and you gradually become part of it." (Stefan)

The - at times detailed — descriptions of far-right violence, however, paint a picture of active engagement. René interacts with individuals who apparently belong to a group that he deems inferior as follows:

“'You gave me a funny look.' That was often a good enough reason. From my perspective: 'You've got black hair, you gave me a stupid look. Come on, let's step outside, now you're in trouble.' Yeah, and when you're out with three, four mates who 
think the same way. Maybe not put it down to the fact that they're foreign, but just because they enjoy fighting, yeah, then it's just hard." (René)

Stefan also has the desire to demonstrate his power as well as his political beliefs in interactions with differently minded people. A demonstration of strength and intimidating behaviour are used to put pressure on political opponents:

"I'd been out to buy bread rolls in the village. And this nice cashier says: No, she doesn't sell to Nazis. Yeah. Then I said: 'Oh, you don't sell to Nazis? No problem.' Left. Called [leader's name], said: 'They're making a fuss here, and so on.' 'Yeah, no problem. You'll be buying bread again soon enough. Wait there, we're coming.' And then ten of us went into the shop and asked if she would sell bread to me NOW. 'Of course, yes. It's on the house.' And ever since, I've been able to buy bread again." (Stefan)

This self-description also details the use of neutralisation techniques not only to justify politically motivated (violent) offences (see also Colvin \& Pisoiu, 2018), but also nonpolitical crimes, such as drug dealing, pimping and property offences that generally do not align with far-right ideology. To remain credible in the eyes of others, as in the present interview setting, and to oneself, the victims are viewed with contempt- "Our foreigners here. ALL criminals." (Udo). Their wrongdoing is played down while the sentencing authorities are condemned, as the following extract shows. Sandro used to write in an online chat group where participants not only posted criminally relevant content, but which motivated serious violent crimes. Yet here, he attempts to trivialise these offences:

"Well, sometimes, let's say, around 80/90 percent of the time, we just wrote meaningless, stupid stuff in the group. And then, like I said, the Federal Prosecutor's Department just PICKED OUT those bits where they BELIEVED we were being SERIOUS. Some things were meant seriously and actually happened. Others weren't, though, and, um, nothing happened, but they thought we were being serious, see?" (Sandro)

The following extract is an even more blatant attempt to direct attention away from the actual offence (sexual exploitation as a prelude to forced prostitution):

"Until she just didn't want to do it anymore and it got violent and she got the police involved, the police gave her this fancy business card from this Weißer Ring [victim support organisation] or something. And, well, this Weißer Ring destroyed me. With compensation claims and what not. Yeah, it's evil, this Weißer Ring. Like I said, you just fall into it." (Stefan)

Stefan portrays himself as a victim, belittles victim support organisations and negates his own responsibility. In this self-description, the biographer no longer perceives himself as radical, the (violent) crimes, which mostly took place within the context of Kameradschaften, are a thing of the past and today his racist ideology is masked by right-wing populist statements about German asylum policy or supposed non-Germans taking advantage of the welfare state. The desire to exert power both now and in the future and to achieve his political visions persists, and for him, options to achieve these aims include pursuing a suitable university degree or a career in politics. René is now involved in party politics. Describing his party's mission in a nutshell, he says:

"So it's, of course, mainly about migration, right. I think that's even in the manifesto, it's the main issue, asylum policy, yeah. Especially since 2015, when it all, you know, as far as I'm concerned, it escalated, so to speak, it's obviously crucial. 
They're exploiting the welfare state. It's a mess, we don't understand each other. It's just difficult to get along." (René)

As in "A decent, staunch, upright German family", here the narrator sees no reason to fully distance himself from the ideology as it is absorbed into right-wing populist narratives. The emergence of right-wing social movements (e.g. Pegida, the Identitarian movement) and the rise of far-right parties, such as AfD, have resulted in media and political debates concerning immigration and asylum that are increasingly characterised by stereotypes and a growing aggressiveness, both of which affirm the biographers' own views (see Laube et al., 2019). In the case of renewed actual or perceived social as well as private rejection, it remains a possibility that the biographers will resort to violence or crime once again to achieve their aims or regain agency.

"You felt discriminated against" is also the self-description used by Jamal when he points to his (perceived) lack of opportunity because of his experiences of structural discrimination. This thus suggests that the ideal type can also be applied to Islamism. Through the news, Jamal hears about the discrimination of people with whom he feels a shared sense of identity. This experience of injustice creates a desire to help fellow Muslims and thus bears striking similarities to the explanation given by right-wing extremists: "They want to spread INJUSTICE again, yeah, and the religious argument was simply that you should help your brothers and sisters"; this strategy is a form of motivational framing (Snow \& Byrd, 2007). Murat also refers to the global discrimination of Muslims and wants to travel to Syria to carry out a suicide bomb attack to support his religious community. In hindsight, however, he sees that this perceived discrimination is exploited by radical groups to recruit members to Islamism:

"If, for example, in the mosque they say, 'Yes, you're a Muslim and they're killing your brothers and sisters and you're just going to sit there?' And then you just think, I'm here and they're there dying and yet we share the same religion, I have to help them. They play on your honour, your loyalty." (Murat)

\section{Discussion}

We have reconstructed four ideal types of biographical self-description outlining the radicalisation process that build on existing research in a number of ways. "Born into the profession" concerns individuals who grow up in a right-wing extremist family where the biographer is exposed solely to far-right ideology from an early age, only finding the tools to disengage in adulthood. "Kind of looking for a family" portrays the search for community. Right-wing extremism offers the biographer both stability and an opportunity to act out their violent tendencies. "A decent, staunch, upright German family" revolves around family tradition. The biographer experiences the racist and superiority-focused values held by relatives, including their (great-)grandparents' National Socialist beliefs, as entirely positive, and eagerly adopts such attitudes. "You felt discriminated against" focuses on negative experiences with people perceived as being of non-German origin. Such encounters trigger feelings of anger and the biographer feels compelled to act. It is clear that the self-descriptions used by right-wing extremists to describe their pathway into radicalisation also appear in connection to Islamism. Future research ought to examine a larger sample 
group to establish whether further ideal types of biographical self-descriptions are also relevant.

Our study has two limitations: not only does our sample contain solely male interviewees but panel mortality is also a factor; it is possible that precisely those interviewees who we were unable to interview a second time were those who became even more radicalised. Moreover, as we only interviewed three former Islamists, the sample size is too small to draw any meaningful conclusions in this area. Despite these limitations, the study does offer key findings. The analysis of the biographies shows that radicalisation not only affects young people in search of purpose whose lives have been characterised by discontinuity. Furthermore, in three of the four ideal types of biographical self-description, the family of origin plays a key role. This is either due to intrafamilial right-wing ideology, glorification of National Socialism, being exposed solely to members of the far-right scene or because family dysfunctionality prompts those affected to look for alternative social bonds.

The core components of far-right ideology, namely, culture-based assumptions of inequality, group-focused enmity, racist attitudes, notions of an anti-democratic order and a focus on violence, appeared in every interview. For all biographers, relevant far-right structures were to hand when they felt a desire to live out their worldview. These structures sometimes even provided the spark that triggered further radicalisation, with social polarisation having an impact on certain biographies. The rapid influx of refugees reaching Germany in 2015 gave individuals who already felt disadvantaged an opportunity to express their discontent at protests. Having contact to like-minded individuals and organised protest groups led them to believe that it was their right - if not their duty - to commit right-wing extremist offences. Similarly, those who were (at times) engaged in Islamism describe being exposed to rising Islamophobia in mainstream society as well as global injustice, which, in their view, compels them to act.

Our findings also underline the significance of Germany's National Socialist past. The Second World War may have ended in 1945, but National Socialism and its legacy continue to be relevant both within families and the wider society. Biographers glorify this period and idealise their (great-)grandfathers who fought in the war. Several decades after the war's end, the hero myth that seems to endure in many families is still to be deconstructed.

Acknowledgements We would like to express our warmest thanks to Katharina Leimbach who has joined us on numerous occasions to interpret interview data. Her insights as a colleague and experienced researcher were extremely valuable. We also express our gratitude to the two anonymous referees for their helpful comments. We are also grateful to Nivene Raafat and Lyam Bittar for their professional translation. This article presents the findings of Biographical analysis concerning courses of radicalisation and deradicalisation, a subproject of the Radicalisation within the Digital Age (RadigZ) research alliance, which was funded by the Federal Ministry of Education and Research between 2017 and 2020 (funding code: 13N14287).

Availability of Data and Material The data is not available publicly but is stored at the department of criminology for the period of 10 years.

Code Availability Does not apply

Funding Open Access funding enabled and organized by Projekt DEAL. German Federal Ministry of Education and Research-13N142807.

\section{Declarations}

Conflict of Interest The authors declare no competing interests.

Open Access This article is licensed under a Creative Commons Attribution 4.0 International License, which permits use, sharing, adaptation, distribution and reproduction in any medium or format, as long 
as you give appropriate credit to the original author(s) and the source, provide a link to the Creative Commons licence, and indicate if changes were made. The images or other third party material in this article are included in the article's Creative Commons licence, unless indicated otherwise in a credit line to the material. If material is not included in the article's Creative Commons licence and your intended use is not permitted by statutory regulation or exceeds the permitted use, you will need to obtain permission directly from the copyright holder. To view a copy of this licence, visit http://creativecommons.org/licenses/by/4.0/.

\section{References}

Baier, D., Manzoni, P., \& Bergmann, M. C. (2016). Einflussfaktoren des politischen Extremismus im Jugendalter: Rechtsextremismus, Linksextremismus und islamischer Extremismus im Ver-gleich. Monatsschrift für Kriminologie und Strafrecht, 99(3), 171-197.

Becker, R. (2010). Persönliche Beziehungsnetzwerke und ihre Bedeutung in der Verfestigung von rechtsextremistischen Orientierungen. In C. Stegbauer \& R. Becker (Eds.), Netzwerkanalyse und Netzwerktheorie (Vol. 46, pp. S. 467-476).

Berger, J. (2018). Extremism. MIT Press.

Bitzan, R. (2017). Geschlechterkonstruktionen und Geschlechterverhältnisse in der extremen Rechten. In F. Virchow, M. Langebach, \& A. Häusler (Eds.), Handbuch Rechtsextremismus (pp. 325-373). Springer Fachmedien Wiesbaden.

Boehnke, L., \& Thran, M. (2019). Defizitäre Populismusbegriffe: Von der Defizitperspektive zur ideologietheoretischen Analysekompetenz. In L. Boehnke, M. Thran, \& J. Wunderwald (Eds.), Rechtspopulismus im Fokus (Vol. 39, pp. 9-30). Springer VS.

Bohnsack, R. (2014). Rekonstruktive Sozialforschung: Einführung in qualitative Methoden (9th ed.). UTB: Vol. 8242. Leverkusen, Leverkusen: UTB; Budrich, Barbara.

Borum, R. (2011a). Radicalization into violent extremism I: A review of social science theories. Journal of Strategic Security, 4(4), 7-36. https://doi.org/10.5038/1944-0472.4.4.1

Borum, R. (2011b). Radicalization into violent extremism II: A review of conceptual models and empirical research. Journal of Strategic Security, 4(4), 37-62. https://doi.org/10.5038/1944-0472.4.4.2

Bögelein, N., \& Meier, J. (2020). Radikalisierung in den Rechtsextremismus aus Netzwerksicht. Eine empirisch begründete Typenbildung. Kriminologie - Das Online-Journal I Criminology - The Online Journal, 2(1), 87-100. https://doi.org/10.18716/ojs/krimoj/2020.1.6

Bögelein, N., Meier, J., \& Neubacher, F. (2017). Modelle von Radikalisierungsverläufen - Einflussfaktoren auf Mikro-, Meso- und Makroebene. Neue Kriminalpolitik, 29(4), 370-378. https://doi.org/10.5771/ 0934-9200-2017-4-370

Canan, C. (2017). The spirit of patriotism - How constitutional is German citizens' national attachment? The case of mosque construction. Journal for Deradicalization, 11, 59-86.

Carlsson, C., Rostami, A., Mondani, H., Sturup, J., Sarnecki, J., \& Edling, C. (2020). A life-course analysis of engagement in violent extremist groups. The British Journal of Criminology, 60(1), 74-92. https:// doi.org/10.1093/bjc/azz048

Colvin, S., \& Pisoiu, D. (2018). When being bad is good? Bringing neutralization theory to subcultural narratives of right-wing violence. Studies in Conflict \& Terrorism, 43(6), 493-508. https://doi.org/10. 1080/1057610X.2018.1452754.

Connell, R. W. (1995). Masculinities. Polity.

Coppock, V., \& McGovern, M. (2014). 'Dangerous minds'? Deconstructing counter-terrorism discourse, radicalisation and the 'psychological vulnerability' of Muslim children and young people in Britain. Children \& Society, 28(3), 242-256. https://doi.org/10.1111/chso.12060

Eckert, R. (2013). Radikalisierung - Eine soziologische Perspektive. Aus Politik und Zeitgeschichte, 63(2931), 11-17.

Elshimi, M. (2015). De-radicalisation interventions as technologies of the self: A Foucauldian analysis. Critical Studies on Terrorism, 8(1), 110-129. https://doi.org/10.1080/17539153.2015.1005933

Frank, A., \& Glaser, M. (2018). Biographie und Rechtsextremismus. In H. Lutz, M. Schiebel, \& E. Tuider (Eds.), Handbuch Biographieforschung. Springer VS. https://doi.org/10.1007/978-3-658-21831-7_30

Frindte, W., Slama, B. B., Dietrich, N., Pisoiu, D., Uhlmann, M., \& Kausch, M. (2016). Wege in die Gewalt. Reihe "Salafismus in Deutschland": 2016/ 3. Leibniz-Institut, Hessische Stiftung Friedens- und Konfliktforschung (HSFK).

Gansewig, A., Walsh, M. (2020). Biografiebasierte Maßnahmen in der schulischen Präventions- und Bildungsarbeit. Eine empirische Betrachtung des Einsatzes von Aussteigern aus extremistischen Szenen unter besonderer Berücksichtigung ehemaliger Rechtsextremer. NOMOS 
Glaser, S. \& Pfeiffer, T. (Hrsg) (2013). Erlebniswelt Rechtsextremismus. Menschenverachtung mit Unterhaltungswert; Hintergründe, Methoden, Praxis der Prävention. Wochenschau Verlag.

Heitmeyer, W. (2005). Gruppenbezogene Menschenfeindlichkeit: Die theoretische Konzeption und empirische Ergebnisse aus 2002, 2003 und 2004. Retrieved from https://digital.zlb.de/viewer/api/v1/ records/15330876_2005_20/files/pdf/03_heitmeyer.pdf

Hellmuth, D. (2015). Counterterrorism and the state: Western responses to 9/11. University of Pennsylvania Press.

Jukschat, N., \& Leimbach, K. (2019). Radikalisierung als hegemoniales Paradigma: Eine empiriebasierte kritische Bestandsaufnahme. BEHEMOTH A Journal on Civilisation, 12(2), 11-23.

Kelle, U., \& Kluge, S. (2010). Vom Einzelfall zum Typus: Fallvergleich und Fallkontrastierung in der qualitativen Sozialforschung. VS Verlag für Sozialwissenschaften.

Kemmesies, U. E. (2006). Terrorismus und Extremismus - der Zukunft auf der Spur: Beiträge zur Entwicklungsdynamik von Terrorismus und Extremismus - Möglichkeiten und Grenzen einer prognostischen Empirie. In U. E. Kemmesies (Ed.), Polizei + Forschung: Vol. 33. Terrorismus und Extremismus - der Zukunft auf der Spur. Beiträge zur Entwicklungsdynamik von Terrorismus und Extremismus - Möglichkeiten und Grenzen einer prognostischen Empirie (pp. 1-39). Luchterhand.

Köttig, M. (2008). Der biographische Ansatz in der Einzelfallhilfe mit rechtsextrem orientierten Mädchen und jungen Frauen. Forum Qualitative Sozialforschung / Forum: Qualitative Social Research, 9(1), Art. 2 Januar 2008

Kraus, B., \& Mathes, C. (2010). Soziale Auffälligkeiten in den Biographien „rechtsmotivierter“ Straftäter. In S. Lützinger (Ed.), Polizei + Forschung: Vol. 40. Die Sicht der Anderen. Eine qualitative Studie zu Biographien von Extremisten und Terroristen (pp. 79-92). Luchterhand.

Kruglanski, A. W., Webber, D., \& Koehler, D. (2019). The radical's journey: How German Neo-Nazis voyaged to the edge and back. Oxford University Press.

Laube, M., Puls, H., \& Tutino, C. (2019). Wandel der Altersstruktur von Tatverdächtigen und Opfern rechtsmotivierter Gewalt? Entwicklung in Nordrhein-Westfalen 2007-2017. Zeitschrift für Jugendhilfe und Jugendkriminalrecht, 3, 196-204.

Leimbach, K. (2019). Die kommunikative Konstruktion einer Problemgruppe: Zur Praktik der Ausstiegsbegleitung bei rechtsextremistischen Jugendlichen. In D. Negnal (Ed.), Die Problematisierung sozialer Gruppen in Staat und Gesellschaft (pp. 145-163). VS Springer.

Lützinger, S. (Ed.). (2010). Die Sicht der Anderen: Eine qualitative Studie zu Biographien von Extremisten und Terroristen. Polizei + Forschung (Vol. 40). Luchterhand.

McCauley, C., \& Moskalenko, S. (2008). Mechanisms of political radicalization: Pathways toward terrorism. Terrorism and Political Violence, 20(3), 415-433. https://doi.org/10.1080/09546550802073367

Meier, J., Bögelein, N., \& Neubacher, F. (2020). Radikalisierungsprozesse aus professioneller Sicht empirische Prüfung eines Modells auf Mikro-, Meso- und Makroebene. NK Neue Kriminalpolitik, 32(4), 502-513.

Möller, K. \& Schumacher, N. (n.d.) (o.J.): Ein- und Ausstiegsprozesse von Skinheads: Abschlussbericht (Forschungsverbund ,Desintegrationsprozesse - Stärkung von Integrationspotenzialen einer modernen Gesellschaft“" No. Projekt 17). Bielefeld.

Pfahl-Traughber, A. (2006). Rechtsextremismus in der Bundesrepublik (4th ed.). C. H. Beck München.

Pfeiffer, T. (2016). Wege in die Szene. Muster und Motive der Einstiegsprozesse in den Rechtsextremismus. In A. Pfahl-Traughber (Ed.), Schriften zur Extremismus- und Terrorismusforschung: Vol. 10. Jahrbuch für Extremismus- und Terrorismusforschung (pp. 122-140). Statistisches Bundesamt.

Presser, L. (2009). The narratives of offenders. Theoretical Criminology, 13(2), 177-200.

Rosenthal, G. (2014). Biographieforschung. In N. Baur \& J. Blasius (Eds.), Handbuch Methoden der empirischen Sozialforschung.

Rosenthal, G. (1995). Erlebte und erzählte Lebensgeschichte: Gestalt und Struktur biographischer Selbstbeschreibungen (pp.509-520). Campus Verlag.

Schütze, F. (1983). Biographieforschung und narratives Interview. Neue Praxis, 3, 283-293.

Shaffer, R. (2017). Music, youth and international links in post-war British fascism: The transformation of extremism. InPalgrave studies in the history of subcultures and popular music. Palgrave Macmillan.

Sigl, J. (2018). Biografische Wandlungen ehemals organisierter Rechtsextremer. Springer VS.

Snow, D., \& Byrd, S. (2007). Ideology, framing processes, and Islamic terrorist movements. Mobilization: An International Quarterly, 12(2), 119-136. https://doi.org/10.17813/maiq.12.2.5717148712w21410

Virchow, F. (2011). Tapfer, stolz, opferbereit - Überlegungen zum extrem rechten Verständnis idealer Männlichkeit. In R. Claus (Ed.), Was ein rechter Mann ist .... Männlichkeiten im Rechtsextremismus (2nd ed., pp. 39-52) (Vol. 68). Dietz.

Willems, H., \& Steigleder, S. (2003). Jugendkonflikte oder hate crime? Täter-Opfer-Konstellationen bei fremdenfeindlicher Gewalt. Journal für Konflikt- und Gewaltforschung, 5(1), 5-28. 
Zick, A. (2017). Extremistische Inszenierungen: Elemente und Pfade von Radikalisierungs- und Deradikalisierungsprozessen. In N. Böckler \& J. Hoffmann (Eds.), Radikalisierung und extremistische Gewalt (pp. 15-36). Verlag für Polizeiwissenschaft.

Publisher's Note Springer Nature remains neutral with regard to jurisdictional claims in published maps and institutional affiliations. 